\title{
Effects of Cymbopogon Winterianus and Ocimum Basilicum against the Stored Phaseolus Vulgaris Bean Pest, Acanthoscelides Obtectus ${ }^{\dagger}$
}

\author{
Álvaro Rodríguez-González *, Óscar González-López, Sara Mayo-Prieto, Guzmán Carro-Huerga, \\ Sara Del Ser-Herrero, Samuel Álvarez-García, Alicia Lorenzana and Pedro A. Casquero \\ Grupo Universitario de Investigación en Ingeniería y Agricultura Sostenible (GUIIAS), Instituto de Medio \\ Ambiente Recursos Naturales y Biodiversidad (INMARENABIO), Escuela de Ingeniería Agraria y Forestal \\ (EIAF), Universidad de Leon, Avenida de Portugal 41, 24071 León, Spain; ogonl@unileon.es (O.G.-L.); \\ smayp@unileon.es (S.M.-P.); gcarh@unileon.es (G.C.-H.); sserh@unileon.es (S.D-S.H.); salvg@unileon.es_(S.A.- \\ G.); alorv@unileon.es (A.L.); pacasl@unileon.es (P.A.C.) \\ * Correspondence: alrog@unileon.es; Tel.: +34-987-291-000 (ext.5058) \\ + Presented at the 1st International Electronic Conference on Plant Science, 1-15 December 2020. Available \\ online: https://iecps2020.sciforum.net/.
}

Published: 1 December 2020

\begin{abstract}
Acanthoscelides obtectus Say (Coleoptera: Chrysomelidae: Bruchinae), is an insect pest that attacks wild and cultivated common beans, Phaseolus vulgaris L. To control insect plagues, it is a priority to choose compounds with different modes of action, with greater selectivity and less persistence. There is an increasing demand in the search for new active substances and natural plant products for pest control for the reduction of adverse effects on human health and environment. Therefore, this investigation evaluated under laboratory conditions, three doses $(24,60$ and $120 \mu \mathrm{L})$ of Cymbopogon winterianuss and Ocimum basilicum essential oils over bean seeds placed in Petri dish in which A. obtectus insects were added before. Treatments of bean seeds with different doses of essential oils provided different survival on $A$. obtectus adults. The essential oils affected the development of $A$. obtectus insects since the greatest doses applied on beans decreased the emergence of the bean weevil. Also, reduced the number of exit holes of insects by damaged beans and the vean weight los, from $2,987 \%$ in control treatment, to $1,014 \%$ and $1,221 \%$ with the dose 120 $\mu \mathrm{L}$ of $C$. winterianuss and $O$. basilicum, respectively. The ability of both doses of $C$. winterianuss and O. basilicum to reduce their longevity, their subsequent emergence from insects, and protect the bean seeds, make these essential oils a suitable tool for the control of adults of this insect pest in small storages.
\end{abstract}

Keywords: bean pest; essential oils; insecticidal properties; development, emergence; bean damage

\section{Introduction}

Phaseolus vulgaris L. is one of the most important legume crops worldwide. This crop can be affected by varius pest, both in fields and in storage. Acanthoscelides obtectus Say (Coleoptera: Chrysomelidae: Bruchinae), is one of those pest that begin its infection in the field continuing the damage during storage, where it causes the greatest losses, to the point of producing the loss of whole crops within a few months [1-3].

So far, the control of this pest has been carried out using synthetic insecticides such as phosphine, pyrethroids, organophosphates, etc. However, these products are highly toxic to human health and the environmental. They are also prone to induce the devolpment of resistances by the insect, therefore complicating its control. As a result, current research focuses on the development of more selective compounds, with low environmental residue and differents modes of action as a more 
sustainable alternative [4,5]. Essencial olis have appeared as one of these alternatives to the use of synthetic chemical products, and their use as insecticides has been increasing lately. Various essential oils have been used as potential fumigants against stored grain insect pests like Callosobruchus maculatus Fabricius (Coleoptera: Chrysomelidae: Bruchinae), Sitophilus oryzae L. (Coleoptera: Curculionidae), A. obctetus or Tribolium castaneum Herbst (Coleoptera: Tenebrionidae) [6-9]. Therefore, natural plant products are a worldwide alternative for the control of mites and insect pests, including A. obtectus [10,11].

Cymbopogon winterianuss Jowitt ex Bor, Poaceae (citronella), is highly appreciated in perfumery and aromatherapy, and posseses antiseptic, antibacterial, antifungal and digestive properties. It has shown repellency and substantial control capacity against many species from different insect orders, as for example, Spodoptera exigua Hübner (Lepidoptera: Noctuidae) [12], Anopheles gambiae Giles (Diptera: Culicidae) [13] and C. maculatus [14].

Ocimum basilicum L., Lamiaceae (basil), commonly used for its medicinal and aromatic characteristic, it is also known for its antioxidant and antimicrobial properties. It has been tested for its insecticidal effects and for the control on several pests of both stored products and crops [15]. Various researches have shown its ability to control pests such as C. maculatus [16], A. obtectus [17], Sithopilus zeamais Motschulsky (Coleoptera: Curculionidae) [18], or Rhyzoperta dominica Fabricius (Coleoptera: Bostrichidae) [19].

The present research has studied the insecticidal potential of $C$. winterianus and $O$. basilicum essential oils against $A$. obtectus on stored beans by non-fumigant applications.

\section{Material and Methods}

\subsection{Insects Rearing}

The original population of $A$. obtectus adults was collected in different bean storage facilities. The insects were reared in glass jars $(150 \mathrm{~mm}$ in diameter and $250 \mathrm{~mm}$ high) with common bean $(P$. vulgaris) seeds and covered with cloth, allowing the gas exchange. Every three days all A. obtectus adults were removed from the jar in order to maintain a population of young adults (1 to 3-day old) ready to use in the experiments. Before and after the treatments, $A$. obtectus adults were kept in a chamber with controlled temperature $\left(24 \pm 1^{\circ} \mathrm{C}\right)$, humidity $(60 \pm 5 \%)$, and a photoperiod of $16 \mathrm{~h}$ of light (luminous intensity of $1000 \mathrm{lux}$ ) and $8 \mathrm{~h}$ of darkness.

\subsection{Essential Oils}

O. basilicum and C. winterianus essential oils obtained by hydrodestillation were purchased from Naissance (Neath, Wales). Volatile components of essential oils were identified by gas chromatography (GC) according to the information provided by the company described above. Analysis for the main compounds are depicted in Table 1.

Table 1. Composition of O. basilicum and C. winterianus essentials oils obtained with GC analysis.

\begin{tabular}{cccccc}
\hline Essential Oil & Compounds (\%) & Total (\%) & Essential Oil & Compounds (\%) & Total (\%) \\
\hline \multirow{3}{*}{ O. basilicum } & Citral (0.70) & & & & \\
& Citronellol (11.50) & & & Estragol (74.00) & \\
& $\begin{array}{l}\text { Citronellal (34.00) } \\
\text { Geraniol (22.00) }\end{array}$ & 71.70 & C. winterianus & & 91.80 \\
& Limonene (3.50) & & & Linalool (17.80) & \\
\hline
\end{tabular}

\subsection{Design of Experiments}

\subsubsection{Experiment 1: Essential Oil Effects on A. obtectus Adults}

This bioassay was conducted to determine the dose-dependent toxicity of $C$. winterianuss and $O$. basilicum essential oils against $A$. obtectus adults. For the application, a Potter Tower (Burkard Scientific Limited, Po Box 55 Uxbridge, Middx UB8 2RT, UK) [20] of manual loading coupled to an 
air compressor was used. The total volume used in each spray was $1 \mathrm{~mL}$, applied on Petri dishes (90 $\mathrm{mm}$ in diameter) over $40 \mathrm{P}$. vulgaris beans at $40 \mathrm{kPa}$. Three doses $(24,60$ and $120 \mu \mathrm{L} /$ petri dish) of $C$. winterianuss and $O$. basilicum oils were diluted in ethanol and five replicates were performed for each of them. A treatment with ethanol (without oil) was used as a control. After application of the treatments, twenty unsexed 1 to 3-day old A. obtectus were placed in the Petri dish with the beans. The Petri dishes were kept in a chamber with controlled temperature $\left(24 \pm 1^{\circ} \mathrm{C}\right)$, humidity $(60 \pm 5 \%)$, and a photoperiod of $16 \mathrm{~h}$ of light (luminous intensity of $1000 \mathrm{lux}$ ) and $8 \mathrm{~h}$ of darkness. In the covers of Petri dishes, 8 holes $\left(8 \mathrm{~mm}^{2}\right)$ were made to avoid the vapour accumulation effect from the treatments. Daily monitoring was carried out during the following 32 days after the application of each dose of essential oil, counting the mortality of A. obtectus adults.

\subsubsection{Experiment 2: Essential Oil Effects on P. vulgaris Beens Damaged by A. obtectus}

From day 32 after the treatment application on the beans, the number of A. obtectus emerged from the beans (first generation) was recorded. Likewise, from day 48 , the number of damaged beans (with at least one hole), the number of holes per bean, and the weight loss of the damaged beans were also recorded in this experiment.

\subsection{Statistical Analysis}

Experiment 1. Survival data of A. obtectus insects were submitted to the Kaplan-Meier estimator and the functions obtained from each treatment were compared by the log-rank test (Mantel-Cox) ( $p$ $<0.05$ ) using IBM SPSS Statistics for Windows, version 26.0. (IBM Corp.: Armonk, NY, USA).

Experiment 2. A randomly completed experiment Generalized Linear Model (GLM) procedure, with three doses for each essential oil and five replicates, was subjected to ANOVA (data means were normally distributed and presented homocedasticity). Differences $(p<0.05)$ in number of damaged beans, number of holes per bean and bean weight loss were examined by mean comparisons using the Least Significant Difference (LSD) test using the same software.

\section{Results}

\subsection{Effects of Beans Sprayed with Essential Oils on the Survival of A. obtectus Insects (Experiment 1)}

Table 2 shows that the type of treatment with essential oil does influence in the survival of the insects (log-rank $\chi 2=103.071 ; \mathrm{df}=6693 ; p<0.001$ ). Insects that were subjected to $120 \mu \mathrm{L}$ of $C$. winterianus and $O$. basilicum essential oils had a significantly lower survival than insect that were subjected to lower doses, as 91.00 and $83.00 \%$ of the evaluated insects died with C.winterianus and $O$. basilicum essential oils, respectively. The insects subjected to $120 \mu \mathrm{L}$ of $O$. basilicum oil had an estimate of 16.01 days of life, significantly lower than that obtained in the rest of doses and the control (22.68 days). If we compare the same doses of both essential oils, only insects subjected to the $120 \mu \mathrm{L}$ of $O$. basilicum had a significantly lower survival than the insects that were subjected to the $120 \mu \mathrm{L}$ dose of C. winterianus (17.89 days) (Table 2). 
Table 2. Survival of A.obtectus insects exposed during 15 days on Petri dishes to beans sprayed with different doses of $C$. winterianus and O. basilicum essential oils and controls.

\begin{tabular}{|c|c|c|c|c|c|c|c|c|}
\hline \multirow{2}{*}{ Treatments } & \multicolumn{3}{|c|}{ Insects } & \multirow{2}{*}{$\begin{array}{c}\text { Mean }{ }^{*} \\
\text { Estimate } \pm \text { SE }\end{array}$} & \multirow{2}{*}{$\begin{array}{l}\text { Median } \\
\text { Estimate }\end{array}$} & \multicolumn{3}{|c|}{ Overall Comparisons ** } \\
\hline & Alive & Dead & Dead (\%) & & & $\mathbf{X}^{2}$ & df & $p$ \\
\hline Control & 76 & 24 & 24.00 & $22.68 \pm 0.48 \mathrm{e}^{\mathrm{a}}$ & 23.00 & & & \\
\hline $\begin{array}{l}\text { C. winterianus } \\
\qquad(24 \mu \mathrm{L})\end{array}$ & 42 & 58 & 58.00 & $20.23 \pm 0.41 \mathrm{dA}^{\mathrm{b}}$ & 20.00 & \multirow[b]{2}{*}{0.571} & \multirow[b]{2}{*}{$(1,198)$} & \multirow[b]{2}{*}{0.450} \\
\hline $\begin{array}{c}\text { O. basilicum } \\
(24 \mu \mathrm{L})\end{array}$ & 41 & 59 & 59.00 & $20.56 \pm 0.52 \mathrm{dA}$ & 20.00 & & & \\
\hline $\begin{array}{l}\text { C. winterianus } \\
(60 \mu \mathrm{L})\end{array}$ & 27 & 73 & 73.00 & $19.55 \pm 0.41 \mathrm{cA}$ & 20.00 & \multirow{2}{*}{0.021} & \multirow{2}{*}{$(1,198)$} & \multirow{2}{*}{0.884} \\
\hline $\begin{array}{c}\text { O. basilicum } \\
(60 \mu \mathrm{L})\end{array}$ & 40 & 60 & 60.00 & $19.12 \pm 0.53 \mathrm{bcA}$ & 19.00 & & & \\
\hline $\begin{array}{l}\text { C. winterianus } \\
(120 \mu \mathrm{L})\end{array}$ & 9 & 91 & 91.00 & $17.89 \pm 1.06 \mathrm{bB}$ & 17.00 & \multirow{2}{*}{7.591} & \multirow{2}{*}{$(1,198)$} & \multirow{2}{*}{0.006} \\
\hline $\begin{array}{c}\text { O. basilicum } \\
(120 \mu \mathrm{L})\end{array}$ & 17 & 83 & 83.00 & $16.01 \pm 0.31 \mathrm{aA}$ & 16.00 & & & \\
\hline
\end{tabular}

* Test of equality of survival distributions for all treatments (Log Rank; Mantel-Cox) (Chi-Square $\left(X^{2}\right)$ $=103.071 ; \mathrm{df}=6,693 ; p<0.001) ;{ }^{* *}$ Test of equality of survival distributions between treatments $(\log$ Rank; Mantel-Cox); ${ }^{a}$ Different lowercase letters indicate significant differences among different dose of essential oils and control; $(p<0.05)$; b Different capital letters indicate significant differences between essential oils within same dose; $(p<0.05)$.

\subsection{Beans Damaged by A. obtectus Insects (Experiment 2)}

Applications of different doses of C. winterianuss and O. basilicum over beans reduced A. obtectus attack, reducing significantly the number of holes per bean affected by the insects after treatment with C. winterianus and O. basilicum essential oils (Table 3) To highlight, the beans treated with the highest doses $(120 \mu \mathrm{L})$ had a significantly $(\mathrm{F}=2.745 ; \mathrm{df}=6.28 ; p=0.032)$ lower number of holes per bean than the $24 \mu \mathrm{L}$ doses $(2.14$ and 3.83 holes per bean with $C$. winterianus and O. basilicum, respectively) and control (3.66 holes per bean). Beans incubated with $A$. obtectus, which were previously treated with different doses of $C$. winterianus and $O$. basilicum essential oil, showed weight losses ranging between $1.01 \%(120 \mu \mathrm{L}$ dose of C. winterianus) and $2.10 \%(24 \mu \mathrm{L}$ dose of O. basilicum), while beans under control treatment had a weight loss $(2.98 \%)$ significantly higher $(\mathrm{F}=4.547 ; \mathrm{df}=$ $6.28 ; p=0.002$ ) than the rest of doses evaluated (Table 3).

Table 3. Number of damaged beans (mean \pm SE), number of holes per bean (mean \pm SE) and bean weight loss $(\% \pm \mathrm{SE})$ caused by $A$. obtectus adults emerged from $40 \mathrm{~g}$ of beans treated in Petri dishes with different doses of $C$. winterianus and O. basilicum essential oils.

\begin{tabular}{|c|c|c|c|c|}
\hline $\begin{array}{c}\text { Essential } \\
\text { Oil }\end{array}$ & $\begin{array}{l}\text { Dose } \\
(\mu \mathrm{L})\end{array}$ & $\begin{array}{c}\text { Number of Damaged Beans (with at } \\
\text { least One Hole) }\end{array}$ & $\begin{array}{c}\text { Number of Holes Per Bean } \\
\text { Damaged }\end{array}$ & $\begin{array}{c}\text { Bean Weight } \\
\text { Loss }(\%)\end{array}$ \\
\hline-- & Control & $4.60 \pm 0.98 \mathrm{a}^{1}$ & $3.66 \pm 0.88 \mathrm{ab}^{1}$ & $2.98 \pm 0.3 \mathrm{a}^{1}$ \\
\hline \multirow{2}{*}{$\begin{array}{l}\text { C. } \\
\text { winterianus }\end{array}$} & 60 & $4.60 \pm 0.40 \mathrm{a}$ & $2.61 \pm 0.23 \mathrm{abc}$ & $1.76 \pm 0.36 \mathrm{bcd}$ \\
\hline & 120 & $5.00 \pm 1.14 \mathrm{a}$ & $1.91 \pm 0.16 \mathrm{c}$ & $1.01 \pm 0.09 \mathrm{~d}$ \\
\hline \multirow{2}{*}{ O. basilicum } & 24 & $3.60 \pm 0.75 a$ & $3.83 \pm 0.87 a$ & $2.10 \pm 0.31 b$ \\
\hline & 120 & $5.20 \pm 1.06 \mathrm{a}$ & $1.68 \pm 0.22 \mathrm{c}$ & $1.22 \pm 0.13 \mathrm{~cd}$ \\
\hline $\mathbf{F}$ & & 0.726 & 2.745 & 4.547 \\
\hline df & & 6.28 & 6.28 & 6.28 \\
\hline$p$ & & 0.633 & 0.032 & 0.002 \\
\hline
\end{tabular}

${ }^{1}$ Different lowercase letters indicate significant differences among beans treated with different doses of essential oils and control; LSD test at 0.05.

\section{Discussion}

The essential oils do not constitute a threat to the environment or to human health, thus they have been portrayed as a possible alternative to synthetic insecticides [21]. The essential oils are 
volatile hydrocarbon mixtures, which have a variety of functional groups [22]. These oils are derived from secondary plant metabolism and play a key role in their development through the defense of the plant against microorganisms and herbivores [22]. Many authors [23-25] have described the essential oils to be composed by substances of various chemical groups, such us terpenes (monoterpenes and sesquiterpenes), phenylpropanoids, alcohols, esters, aldehydes, ketones, among others. The biological activity of essential oils depends not only on their chemical composition, but also on the concentration and proportion of these substances [23-25].

These essential oils exhibited similar patterns for insecticidal activity over A. obtectus when sprayed directly over beans in Petri dishes using different doses, being the highest insecticidal activities obtained in the first 15 days for the $120 \mu \mathrm{L}$ doses of both essential oils. The greater insecticidal activity of both oils did not exceed 15 days after application. This translated into a lower survival of the insects, observed in the higher doses of the oils, which reduced the survival of the insects to approximately 17 and 16 days of life with C. winterianus and O. basilicum. In the same range of days, this effect is well described by Ilboudo et al. [26] for several other essential oils. Loss of activity for essential oils are normally due to degradation of the active compounds. In this respect, essential oils containing more hydrogenated compounds are more susceptible to oxidation [8]. Various studies with essential oils obtained from species of the genus Ocimum spp. showed good results regarding their insecticidal effect against insect pests that attack grains, producing a lower survival of the insects. Kéita et al. [7] evaluated (by fumigation) the effect of $O$. basilicum and $O$. gratissimum for the control of $C$. maculatus and obtained 80 and $70 \%$ mortality of the insect population evaluated with $25 \mu \mathrm{L}$. Rozman et al. [27] reported toxicity against T. castaneum, Rhyzopertha dominica (Coleoptera: Bostrichidae), and S. oryzae in fumigation with Linalool, one of the main components of basil essential oil. Linalool was highly effective against $R$. dominica, and caused $100 \%$ mortality at the lowest tested concentration ( $0.1 \mathrm{~mL} / 720 \mathrm{~mL}$ of volume). Ogendo et al. [28] obtained a 98, 99, and 100\% mortality against $R$. dominica, Oryzaephilus surinamensis L. (Coleoptera: Silvanidae), and Callosobruchus chinensis L. (Coleoptera: Chrysomelidae), using $1 \mu \mathrm{L}$ of O. gratissimum essential oil per litre of air.

Other studies have shown diverse activities and effects of $C$. winterianus, such us insect repellency [29], larvicidal effect for certain mosquito species [30], and insecticidal activity against Frankliniella schultzei Trybom (Thysanoptera: Thripidae) and Myzus persicae Sulzer (Homoptera: Aphididae) [31]. Citronella oil caused also repellency on C. maculatus adults [14], and feed deterrence and larval mortality on S. frugiperda Walker (Lepidoptera: Noctuidae) [32].

C. winterianus and O. basilicum essential oils exhibited a significant reductions on number of damaged beans produced by $A$. obtectus when greater doses were applied over the beans. In addition, the high doses $(120 \mu \mathrm{L})$ of $C$. winterianus and O. basilicum oils generated lower bean weight loss in the damaged beans, showing the toxic activity of this essential oil through its Linalool component. This reduction in the severity of the attack shown by A. obtectus towards treated beans has also been observed by Rodríguez-González et al. [33-35] using biological control agents, bacterial proteins [36], and essential oils [37].

\section{Conclusions}

O. basilicum and C. winterianus essential oils affected the development of $A$. obtectus insects since the greatest doses applied on beans decreased the emergence of the bean weevil. Also, they reduced the number of exit holes of insects per damaged bean and the bean weight loss, from $2.987 \%$ in control treatment, to $1.014 \%$ and $1.221 \%$ with $120 \mu \mathrm{L}$ of $C$. winterianus and O. basilicum, respectively. The ability of both doses of $C$. winterianus and $O$. basilicum to reduce the insect longevity, their subsequent emergence from beans, and protect the bean seeds, make these essential oils a suitable tool for the control of adults of this insect pest in small storages.

Author Contributions: A.R.-G., O.G.-L. and S.M.-P. designed the experiment. G.C.-H., S.D-S.-H. and S.A.-G. conducted the experiments. A.R.-G., A.L. and P.A.C. performed statistical analysis. A.R.-G. and P.A.C. prepared the manuscript. All authors have read and agreed to the published version of the manuscript. 
Acknowledgments: This work was funded by the Ministry of Science, Innovation and Universities (Government of Spain), according to the Resolution of 27 July 2018, (BOE No. 184, of 31 July) through the grant awarded to Álvaro Rodríguez González (PTA2017-14403-I).

Conflicts of Interest: The authors declare no conflict of interest.

\section{References}

1. Paul, U. V.; Lossini, J.S.; Edwards, P.J.; Hilbeck, A. Effectiveness of products from four locally grown plants for the management of Acanthoscelides obtectus (Say) and Zabrotes subfasciatus (Boheman) (both Coleoptera: Bruchidae) in stored beans under laboratory and farm conditions in Northern T. J. Stored Prod. Res. 2009, 45, 97-107, doi:10.1016/j.jspr.2008.09.006.

2. Vilca Mallqui, K.S.; Oliveira, E.E.; Guedes, R.N.C. Competition between the bean weevils Acanthoscelides obtectus and Zabrotes subfasciatus in common beans. J. Stored Prod. Res. 2013, 55, 32-35, doi:10.1016/j.jspr.2013.07.004.

3. Baier, A.H.; Webster, B.D. Control of Acanthoscelides obtectus Say (Coleoptera: Bruchidae) in Phaseolus vulgaris L. seed stored on small farms-I. Evaluation of damage. J. Stored Prod. Res. 1992, 28, 289-293, doi:10.1016/0022-474X(92)90011-E.

4. Regnault-Roger, C.; Vincent, C.; Arnason, J.T. Essential oils in insect control: Low-risk products in a highstakes world. Annu. Rev. Entomol. 2012, 57, 405-424, doi:10.1146/annurev-ento-120710-100554.

5. Rodríguez-González, A.; Mayo, S.; González-López, O.; Reinoso, B.; Gutierrez, S.; Casquero, P.A. Inhibitory activity of Beauveria bassiana and Trichoderma spp. on the insect pests Xylotrechus arvicola (Coleoptera: Cerambycidae) and Acanthoscelides obtectus (Coleoptera: Chrisomelidae: Bruchinae). Environ. Monit. Assess. 2017, 189, doi:10.1007/s10661-016-5719-z.

6. Devi, M.A.; Sahoo, D.; Singh, T.B.; Rajashekar, Y. Toxicity, repellency and chemical composition of essential oils from Cymbopogon species against red flour beetle Tribolium castaneum Herbst (Coleoptera: Tenebrionidae). J. fur Verbraucherschutz und Leb. 2020, 15, 181-191, doi:10.1007/s00003-019-01264-y.

7. Kéita, S.M.; Vincent, C.; Schmit, J.P.; Arnason, J.T.; Bélanger, A. Efficacy of essential oil of Ocimum basilicum L. and O. gratissimum L. applied as an insecticidal fumigant and powder to control Callosobruchus maculatus (Fab.) [Coleoptera: Bruchidae]. J. Stored Prod. Res. 2001, 37, 339-349, doi:10.1016/S0022-474X(00)00034-5.

8. Kim, S. Il; Roh, J.Y.; Kim, D.H.; Lee, H.S.; Ahn, Y.J. Insecticidal activities of aromatic plant extracts and essential oils against Sitophilus oryzae and Callosobruchus chinensis. J. Stored Prod. Res. 2003, 39, 293-303, doi:10.1016/S0022-474X(02)00017-6.

9. Mazzonetto, F.; Vendramim, J.D. Efeito de pós de origem vegetal sobre Acanthoscelides obtectus (Say) (Coleoptera: Bruchidae) em feijão armazenado. Neotrop. Entomol. 2003, 32, 145-149, doi:10.1590/S1519566X2003000100022.

10. Papachristos, D.P.; Karamanoli, K.I.; Stamopoulos, D.C.; Menkissoglu-Spiroudi, U. The relationship between the chemical composition of three essential oils and their insecticidal activity against Acanthoscelides obtectus (Say). Pest Manag. Sci. 2004, 60, 514-520, doi:10.1002/ps.798.

11. Regnault-Roger, C.; Hamraoui, A.; Holeman, M.; Theron, E.; Pinel, R. Insecticidal effect of essential oils from Mediterranean plants upon Acanthoscelides obtectus Say (Coleoptera, Bruchidae), a pest of kidney bean (Phaseolus vulgaris L.). J. Chem. Ecol. 1993, 19, 1233-1244, doi:10.1007/BF00987383.

12. Silva, C.T.S.; Wanderley-Teixeira, V.; Cunha, F.M.; Oliveira, J. V.; Dutra, K.A.; Navarro-Ferraz, D.M.A.; Teixeira, A.A.C. Effects of citronella oil (Cymbopogon winterianus Jowitt ex Bor) on Spodoptera frugiperda (J. E. Smith) midgut and fat body. Biotech. Histochem. 2018, 93, 36-48, doi:10.1080/10520295.2017.1379612.

13. Deletre, E.; Chandre, F.; Williams, L.; Duménil, C.; Menut, C.; Martin, T. Electrophysiological and behavioral characterization of bioactive compounds of the Thymus vulgaris, Cymbopogon winterianus, Cuminum cyminum and Cinnamomum zeylanicum essential oils against Anopheles gambiae and prospects for their use as bednet treatments. Parasites and Vectors 2015, 8, 316, doi:10.1186/s13071-015-0934-y.

14. Gusmão, N.M.S.; de Oliveira, J. V.; Navarro, D.M. d. A.F.; Dutra, K.A.; da Silva, W.A.; Wanderley, M.J.A. Contact and fumigant toxicity and repellency of Eucalyptus citriodora Hook., Eucalyptus staigeriana F., Cymbopogon winterianus Jowitt and Foeniculum vulgare Mill. Essential oils in the management of $<\mathrm{i}>$ Callosobruchus maculatus<. J. Stored Prod. Res. 2013, 54, 41-47, doi:10.1016/j.jspr.2013.02.002.

15. Traka, C.K.; Petrakis, E.A.; Kimbaris, A.C.; Polissiou, M.G.; Perdikis, D.C. Effects of Ocimum basilicum and Ruta chalepensis hydrosols on Aphis gossypii and Tetranychus urticae. J. Appl. Entomol. 2018, 142, 413-420, doi:10.1111/jen.12486. 
16. Kéïta, S.M.; Vincent, C.; Schmit, J.P.; Ramaswamy, S.; Bélanger, A. Effect of various essential oils on Callosobruchus maculatus (F.) (Coleoptera: Bruchidae). J. Stored Prod. Res. 2000, 36, 355-364, doi:10.1016/S0022-474X(99)00055-7.

17. Papachristos, D.P.; Stamopoulos, D.C. Repellent, toxic and reproduction inhibitory effects of essential oil vapours on Acanthoscelides obtectus (Say) (Coleoptera: Bruchidae). J. Stored Prod. Res. 2002, 38, 117-128, doi:10.1016/S0022-474X(01)00007-8.

18. Iqbal, J.; Khan, E.A. Evaluation of some plant extracts against maize weevil, Sitophilus zeamais (Coleoptera: Curculionidae) under laboratory conditions. Pakistan J. Agric. Sci. 2017, 54, 737-741, doi:10.21162/PAKJAS/17.5988.

19. de Souza, V.N.; Ferreira de Oliveira, C.R.; Cysneiros Matos, C.H.; Florentino de Almeida, D.K. Fumigation toxicity of essential oils against Rhyzopertha dominica (F.) in stored maize grain. Rev. Caatinga 2016, 29, 435440, doi:10.1590/1983-21252016v29n220rc.

20. Potter, C. An improved laboratory apparatus for applying direct sprays and surface films, with data on the electrostatic charge on atomized spray fluids. Ann. Appl. Biol. 1952, 39, 1-28, doi:10.1111/j.17447348.1952.tb00993.x.

21. Potter, C. An improved laboratory apparatus for applying direct sprays and surface films, with data on the electrostatic charge on atomized spray fluids. Ann. Appl. Biol. 1952, 39, 1-28.

22. Cruz, G.S.; Wanderley-Teixeira, V.; da Silva, L.M.; Dutra, K.A.; Guedes, C.A.; de Oliveira, J.V.; Navarro, D.M.A.F.; Araújo, B.C.; Teixeira, Á.A.C. Chemical composition and insecticidal activity of the essential oils of Foeniculum vulgare Mill., Ocimum basilicum L., Eucalyptus staigeriana F. Muell. ex Bailey, Eucalyptus citriodora Hook and Ocimum gratissimum L. and and Their Major Components on Spodoptera frugiperda (Lepidoptera: Noctuidae). J. Essent. Oil-Bear. Plants 2017, 20, 1360-1369, doi:10.1080/0972060X.2017.1383192.

23. Siani, C.A.; Sampaio, A.L.F.; Sousa, M.C.; Henriques, M.G.M.O.; Ramos, M.F.S. Óleos essenciais: Potenciais inflamatórios. Biotecnol. Ciência e Desenvolv. 2000, 16, 38-43.

24. da Silveira, S.M.; Cunha Jr., A.; Scheuermann. G.N.; Secchi, F.L.; Verruz, S.; Krohn, M.; Werneck Vieira, C.R. Chemical composition and antibacterial activity of essential oils from Cymbopogon winterianus (citronella), Eucalyptus paniculata (eucalyptus) and Lavandula angustifolia (lavender). Rev. do Inst. Adolfo Lutz 2012, 71, 462-470.

25. Ringuelet, J.A.; Ocampo, R.; Henning, C.; Padín, S.; Urritia, M.I.; Bello, G.D. Actividad insecticida del aceite esencial de Lippia alba (Mill.) N. E. Brown sobre Tribolium castaneum Herbst. en granos de trigo (Triticum aestivum L.)| Revista Brasileira de Agroecologia. Rev. Bras. Agroecol. 2014, 9, 214-222.

26. Ilboudo, Z.; Dabiré, L.C.B.; Nébié, R.C.H.; Dicko, I.O.; Dugravot, S.; Cortesero, A.M.; Sanon, A. Biological activity and persistence of four essential oils towards the main pest of stored cowpeas, Callosobruchus maculatus (F.) (Coleoptera: Bruchidae). J. Stored Prod. Res. 2010, 46, 124-128, doi:10.1016/j.jspr.2009.12.002.

27. Rozman, V.; Kalinovic, I.; Korunic, Z. Toxicity of naturally occurring compounds of Lamiaceae and Lauraceae to three stored-product insects. J. Stored Prod. Res. 2007, 43, 349-355, doi:10.1016/j.jspr.2006.09.001.

28. Ogendo, J.O.; Kostyukovsky, M.; Ravid, U.; Matasyoh, J.C.; Deng, A.L.; Omolo, E.O.; Kariuki, S.T.; Shaaya, E. Bioactivity of Ocimum gratissimum L. oil and two of its constituents against five insect pests attacking stored food products. J. Stored Prod. Res. 2008, 44, 328-334, doi:10.1016/j.jspr.2008.02.009.

29. Martins, R.M. Estudio in vitro de la acción acaricida del aceite esencial de la gramínea citronela de Java (Cymbopogon winterianus Jowitt) en la garrapata Boophilus microplus. Rev. Bras. Plantas Med. 2006, 8, 71-78.

30. Furtado, R.F.; de Lima, M.G.A.; Manoel, A.N.; Bezerra, J.N.S.; Silva, M.G. d. V. Atividade larvicida de óleos essenciais contra Aedes aegypti L. (Diptera: Culicidae). Neotrop. Entomol. 2005, 34, 843-847, doi:10.1590/S1519-566X2005000500018.

31. Pinheiro, P.F.; de Queiroz, V.T.; Rondelli, V.M.; Costa, A.V.; Marcelino, T. de P.; Pratissoli, D. Insecticidal activity of citronella grass essential oil on Frankliniella schultzei and Myzus persicae. Ciência e Agrotecnologia 2013, 37, 138-144, doi:10.1590/S1413-70542013000200004.

32. Labinas, A.M.; Maringa, W.B. Effect of Java grass (Cymbopogon winterianus Jowitt) essential oil on fall armyworm Spodoptera frugiperda (JE Smith, 1797)(Lepidoptera, Noctuidae). Maringa 2002, 24, 1401-1405.

33. Rodríguez-González, A.; Casquero, P.A.; Suárez-Villanueva, V.; Carro-Huerga, G.; Álvarez-García, S.; Mayo-Prieto, S.; Lorenzana, A.; Cardoza, R.E.; Gutiérrez, S. Effect of trichodiene production by Trichoderma harzianum on Acanthoscelides obtectus. J. Stored Prod. Res. 2018, 77, 231-239, doi:10.1016/j.jspr.2018.05.001. 
34. Rodríguez-González, A.; Casquero, P.A.; Cardoza, R.E.; Gutiérrez, S. Effect of trichodiene synthase encoding gene expression in Trichoderma strains on their effectiveness in the control of Acanthoscelides obtectus. J. Stored Prod. Res. 2019, 83, 275-280, doi:10.1016/j.jspr.2019.07.006.

35. Rodríguez-González, Á.; Campelo, M.P.; Lorenzana, A.; Mayo-Prieto, S.; González-López, Ó.; ÁlvarezGarcía, S.; Gutiérrez, S.; Casquero, P.A. Spores of Trichoderma strains sprayed over Acanthoscelides obtectus and Phaseolus vulgaris L. beans: Effects in the biology of the bean weevil. J. Stored Prod. Res. 2020, 88, 101666, doi:10.1016/j.jspr.2020.101666.

36. Rodríguez-González, A.; Porteous-Álvarez, A.J.; del Val, M.; Casquero, P.A.; Escriche, B. Toxicity of five Cry proteins against the insect pest Acanthoscelides obtectus (Coleoptera: Chrisomelidae: Bruchinae). J. Invertebr. Pathol. 2020, 169, doi:10.1016/j.jip.2019.107295.

37. Rodríguez-González, A.; Álvarez-García, S.; González-López, O.; da Silva, F.; Casquero, P.A. Insecticidal properties of Ocimum basilicum and Cymbopogon winterianus against Acanthoscelides obtectus, insect pest of the common bean (Phaseolus vulgaris, L.). Insects 2019, 10, doi:10.3390/insects10050151.

Publisher's Note: MDPI stays neutral with regard to jurisdictional claims in published maps and institutional affiliations.

(C) 2020 by the authors. Licensee MDPI, Basel, Switzerland. This article is an open access article distributed under the terms and conditions of the Creative Commons Attribution (CC BY) license (http://creativecommons.org/licenses/by/4.0/). 